\title{
HSP27 modulates epithelial to mesenchymal transition of lung cancer cells in a Smad-independent manner
}

\author{
HIDEAKI MIZUTANI, TETSUYA OKANO, YUJI MINEGISHI, KUNIKO MATSUDA, \\ JUNKO SUDOH, KAZUHIRO KITAMURA, RINTARO NORO, CHIE SOENO, \\ AKINOBU YOSHIMURA, MASAHIRO SEIKE and AKIHIKO GEMMA \\ Department of Internal Medicine, Division of Pulmonary Medicine/Infection and Oncology, \\ Nippon Medical School, Tokyo 113-8603, Japan
}

Received July 14, 2010; Accepted September 13, 2010

DOI: $10.3892 / 01.2010 .190$

\begin{abstract}
Epithelial to mesenchymal transition (EMT) is induced by transforming growth factor- $\beta 1$ (TGF- $\beta 1$ ) and is a crucial event for cancer cells to acquire invasive and metastatic phenotypes. However, the signals that induce EMT in cancer cells have yet to be adequately defined. In this study, a proteomic investigation was performed to understand the signaling pathway of the EMT of lung cancer using two-dimensional difference gel electrophoresis (2D-DIGE) and mass spectrometry. The protein expression profiles of A549 were compared to those of A549 cells treated with TGF- $\beta 1$. Of more than 2,000 protein spots shown by $2 \mathrm{D}$-DIGE, 53 were found to be up- or down-regulated upon induction with TGF- $\beta 1$. In the 53 protein spots, the protein level of heat shock protein (HSP) 27 was found to increase significantly. HSP27 protein was higher in two different lung cancer cell lines, demonstrating the EMT phenomenon with TGF- $\beta 1$. Notably, the silencing of HSP27 enhanced spindle integration, resulting in an additive effect with TGF- $\beta 1$-induced EMT. Furthermore, the TGF- $\beta 1$-induced HSP27 increase was not affected by the suppression of Smad 2 and Smad3 in A549 cells. These results suggest that HSP27 was involved in TGF- $\beta 1$-induced EMT in a Smad-independent manner in lung cancer cells and may provide an effective clinical strategy in lung cancer patients whose tumors are dependent on TGF- $\beta 1$-induced EMT.
\end{abstract}

\section{Introduction}

Epithelial to mesenchymal transition (EMT) is a process by which cells undergo a morphological switch from the epithelial polarized phenotype to the mesenchymal fibroblastoid

Correspondence to: Dr Masahiro Seike, Department of Internal Medicine, Division of Pulmonary Medicine/Infection and Oncology, Nippon Medical School, 1-1-5 Sendagi, Bunkyo-ku, Tokyo 113-8603, Japan

E-mail: mseike@nms.ac.jp

Key words: lung cancer, epithelial to mesenchymal transition, HSP27, transforming grow th factor- $\beta 1$, proteomics, two-dimensional difference gel electrophoresis phenotype, induced by transforming growth factor- $\beta$ (TGF- $\beta$ ). EMT is characterized by loss of epithelial differentiation markers, such as E-cadherin, and the induction of mesenchymal markers, such as vimentin and fibronectin. EMT was shown to play a key role in various processes during embryonic development, chronic inflammation and fibrosis $(1,2)$. Moreover, EMT was noted during tumor cell invasion and metastasis in various solid tumors, such as lung cancer (3-5). Mesenchymal cells arising from EMT contribute to the process of tumor cell invasion. Taken together, these findings suggest that EMT is a crucial event for cancer cells to acquire invasive and metastatic phenotypes.

Lung cancer is the leading cause of cancer-related death in Japan and worldwide. Patient prognosis remains poor despite recent improvements in chemotherapies and moleculartargeted therapies. The identification of sensitive and specific biomarkers that predict metastasis, prognosis and drug sensitivity may have a clinically significant effect on lung cancer treatment strategies (6-9). Studies have described the involvement of EMT in various tumors (3-5). A number of studies reported that transforming growth factor- $\beta 1$ (TGF- $\beta 1$ )-induced EMT is correlated with carcinogenesis, metastasis and resistance to chemotherapy in lung cancer $(5,10-16)$. These findings demonstrated that suppression of EMT may be used as a target for the chemoprevention and treatment of lung cancer. The Smad signal pathway is well known as a major transducer of TGF- $\beta$ signaling. However, the potential signaling pathway during EMT of lung cancer requires further investigation.

This study analyzed the protein expression profiles of lung cancer cells to clarify the signaling mechanisms of EMT using two-dimensional difference gel electrophoresis (2D-DIGE) and mass spectrometry. Heat shock protein 27 (HSP27) was identified as a molecule that increased during TGF- $\beta 1$-induced EMT in lung cancer cells in a Smad-independent manner. Furthermore, the suppression of HSP27 using specific small interfering RNA (siRNA) accelerated TGF- $\beta 1$-induced EMT in A549 cells, a lung adenocarcinoma cell line.

\section{Materials and methods}

Cell culture. This study used well-characterized lung adenocarcinoma cell lines $(17,18)$. A549 was purchased from 
the American Type Culture Collection; RERF-LC-KJ and LC2-ad were obtained from the Riken Cell Bank (Ibaraki, Japan); and PC9 was obtained from Immuno-Biological Laboratories (Gunma, Japan). Lung cancer cell lines were maintained in RPMI-1640 (Gibco) supplemented with $10 \%$ fetal bovine serum.

$2 D-D I G E$ and mass spectrometry. On reaching 80-90\% confluence, the cells were washed twice with phosphatebuffered saline, scraped off into a $1.5-\mathrm{ml}$ tube and briefly centrifuged. The cell pellets were incubated for $30 \mathrm{~min}$ in lysis buffer containing $6 \mathrm{M}$ urea, $2 \mathrm{M}$ thiourea, $1 \%$ Triton $\mathrm{X}-100$ and 3\% [(3-Cholamidopropyl)dimethylammonio]-1propanesulfonate. Following centrifugation at 15,000 rpm for $30 \mathrm{~min}$, the cell proteins were recovered from the supernatant and the protein concentration was measured using a Protein Assay Kit (Bio-Rad Laboratories, Inc., Hercules, CA, USA). The proteins were labeled with fluorescent dyes developed for the 2D-DIGE system, as previously described (GE Healthcare Bio-Sciences Corp., Piscataway, NJ, USA) $(19,20)$. The gels were scanned at appropriate wavelengths for $\mathrm{Cy} 3$ and $\mathrm{Cy} 5$ dyes with Typhoon (GE Healthcare Bio-Sciences Corp.). The spots were detected and quantified using DeCyder software (GE Healthcare Bio-Sciences Corp.). Protein identification was performed by mass spectrometry. Mass spectrometric analysis of tryptic digests was performed using Magic 2000 (GE Healthcare Bio-Sciences Corp.) and peptide mass mapping was performed using Mascot search.

Antibodies and Western blot analysis. The cells were lysed in buffer $(\mathrm{pH}$ 7.6) containing $50 \mathrm{mM}$ Tris- $\mathrm{HCl}, 150 \mathrm{mM}$ $\mathrm{NaCl}, 0.1 \%$ sodium dodecyl sulfate, $1 \%$ Nonidet P-40 and $0.5 \%$ sodium-deoxycholate. The lysates were maintained on ice for $30 \mathrm{~min}$ and then centrifuged at 13,000 x $\mathrm{g}$ for $30 \mathrm{~min}$. The supernatant was collected, and $10 \mu \mathrm{g}$ of protein were separated by gel electrophoresis on $12 \%$ gels and transferred to nitrocellulose membranes by immunoblotting using a chemiluminescence system (GE Healthcare Bio-Sciences Corp.). The antibodies for detecting HSP27, Smad2, Smad3, phospho-Smad2 (p-Smad2), phospho-Smad3 (p-Smad3) and $\beta$-actin were purchased from Cell Signaling Technology (Beverley, MA, USA).

Small interfering RNA (siRNA) transfection. Transfections were performed at $\sim 50 \%$ cell confluency. Briefly, $1.0 \times 10^{5}$ A549 cells per well (6 wells) were seeded in OPTI-MEM I (Gibco 3198) without supplementary antibiotics. To prepare siRNA, $4 \mu \mathrm{l}$ of Lipofectamine ${ }^{\mathrm{TM}} 2000$ (Invitrogen, Carlsbad, CA, USA), which is a transfection reagent of siRNA, were mixed with $196 \mu \mathrm{l}$ of OPTI-MEM I (Solution I). In addition, 100 pmol siRNA solution was diluted with $200 \mu \mathrm{l}$ of OPTI-MEM I and incubated for $5 \mathrm{~min}$ at room temperature (Solution II). Solutions I and II were then mixed and incubated for $20 \mathrm{~min}$ at room temperature. siRNA and this reagent complex were added to the A549 cells in OPTI-MEM I ( $2 \mathrm{ml} /$ well). The final concentration of siRNA was $50 \mathrm{nM}$. The A549 cells were incubated for $48 \mathrm{~h}$ after transfection. siGENOME SMART pool Human SMAD2 no. M003561 (Dharmacon Inc., Lafayette, CO, USA) was used as siSmad2, siGENOME SMART pool Human SMAD3 no. M020067
(Dharmacon) as siSmad3 and siGENOME SMART pool Human HSPB1 no. M005269 (Dharmacon) as siHSP27, with siGENOME SMART pool non-targeting siRNA no. D001206 (Dharmacon) as the control.

\section{Results}

Identification of the proteins whose expression was affected by EMT of A549 cells. TGF- $\beta 1$ is known to stimulate the EMT of A549 lung cancer cells (1-4). In this study, A549 cells treated with $5 \mathrm{ng} / \mathrm{ml}$ of TGF- $\beta 1$ for $72 \mathrm{~h}$ were designated as A549/TGF- $\beta 1$. We observed that while the parent A549 cells exhibited a classic epithelial morphology, A549/TGF- $\beta 1$, by contrast, appeared less uniformly epithelial (Fig. 1A).

2D-DIGE was used to compare the protein expression profiles of A549 cells to those of A549/TGF- $\beta 1$, in order to identify the protein populations whose expression was associated with EMT in lung cancer. Fig. 1B shows a representative Cy5 image unique to A549/TGF- $\beta$ cells. More than 2,000 spots were noted using 2D-DIGE. Computer-assisted quantitative analysis identified 32 protein spots with increased intensity and 21 protein spots with decreased intensity when compared to A549 cells ( $\mathrm{p}<0.05$ ) (Fig. 1B). Mass spectrometry successfully identified 53 proteins. Of these, 14 had a $>2.0$-fold change in the level of expression in A549/TGF- $\beta 1$ cells compared to A549 cells (Table I). The most significant increase in expression levels in A549/TGF- $\beta 1$ cells compared to A549 cells was observed with HSP27 protein, which increased by 9.2 -fold. HSP27 protein expression levels were also higher in RERF-LC-KJ and LC2-ad cells, which also showed the EMT phenomenon, following treatment of the respective parent cells with TGF- $\beta 1$. By contrast, HSP27 expression levels in PC9 cells were not affected by exposure to TGF- $\beta 1$ (Fig. 1C). PC9 cells did not exhibit signs of EMT following stimulation with TGF- $\beta 1$ (data not shown).

To confirm the increased expression of HSP27 protein observed by 2D-DIGE, Western blot analysis was performed using HSP27 antibody. Western blot analysis showed that the expression of HSP27 was increased in A549/TGF- $\beta 1$ cells compared to A549 cells (Fig. 1D). Therefore, HSP27 protein was used in further functional studies of EMT.

Knockdown of HSP27 in A549 and A549/TGF- $\beta 1$ cells and the effect on EMT. To investigate the effect of HSP27 on TGF- $\beta 1$-induced EMT, HSP27 protein was knocked down in A549 cells. Control or specific HSP27 siRNA was transfected into A549 cells for $24 \mathrm{~h}$, and the A549 and A549/TGF- $\beta 1$ cells were examined for signs of morphological change after 48 h. Notably, silencing of HSP27 in A549/TGF- $\beta 1$ cells enhanced spindle integration, resulting in an additive effect with TGF- $\beta 1$-induced EMT (Fig. 2A). The expression of EMT markers was evaluated to confirm the occurrence of EMT by Western blot analysis. The expression levels of EMT markers in A549 and A549/TGF- $\beta 1$ cells treated with HSP27 siRNA were examined. A549/TGF- $\beta 1$ cells treated with HSP27 siRNA exhibited a reduced E-cadherin expression and increased N-cadherin expression when compared to A549/ TGF- $\beta 1$ cells treated with control siRNA (Fig. 2B). These observations suggest that the inhibition of HSP27 protein, which accelerates the EMT process, is mediated by TGF- $\beta 1$. 
A
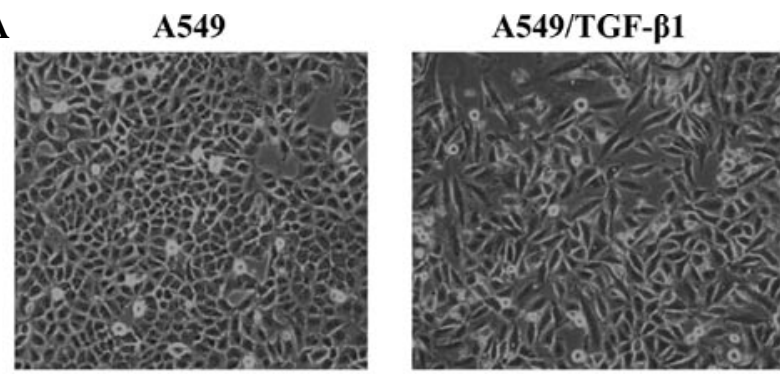

B

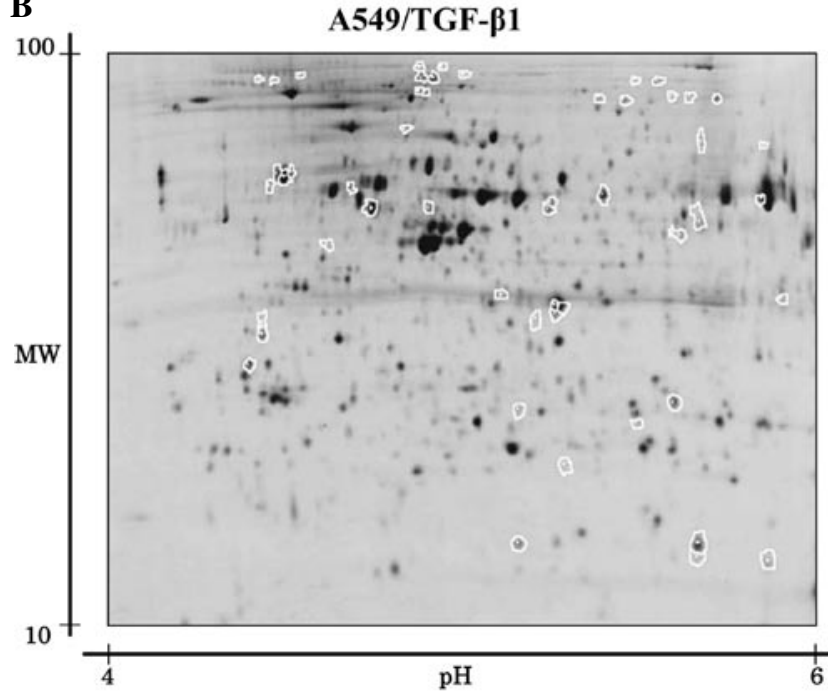



D

A549

A549/TGF-ß1

HSP27

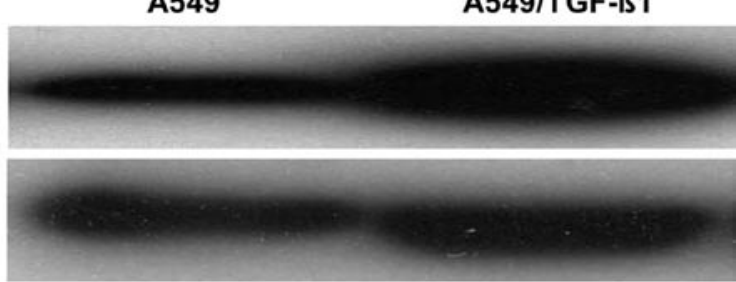

Figure 1. (A) TGF- $\beta 1$-stimulated EMT of A549 lung cancer cells. A549 cells were treated with $5 \mathrm{ng} / \mathrm{ml}$ of TGF- $\beta 1$ for $72 \mathrm{~h}$ and then designated as A549/ TGF- $\beta 1$ cells. The cells were observed under a light microscope. A549 cells exhibited a classic epithelial morphology. By contrast, A549/TGF- $\beta 1$ appeared to be less uniformly epithelial. (B) A549/TGF- $\beta 1$ cells were subjected to 2D-DIGE. (C) Expression levels of HSP27 following TGF- $\beta 1$ treatment were analyzed in four lung cancer cell lines using 2D-DIGE. Among the four cell lines, EMT was observed in A549, RERF-LC-KJ and LC2-ad cells, but not PC9, following TGF- $\beta 1$ stimulation. Data are the mean \pm SD from three independent experiments. $"$ p $<0.05$ when compared to the respective parent cells. (D) HSP27 expression was analyzed by Western blot analysis. Compared to the A549 cells, A549/TGF- $\beta 1$ revealed an increased level of HSP27.

Table I. A list of the identified proteins, the expression of which was affected by EMT of A549 cells.

\begin{tabular}{|c|c|c|c|c|c|c|}
\hline $\begin{array}{l}\text { Spot } \\
\text { no. }\end{array}$ & $\begin{array}{c}\text { Fold } \\
\text { change }\end{array}$ & $\begin{array}{l}\text { NCBI ID no./ } \\
\text { accession no. }\end{array}$ & Protein identified $^{\mathrm{a}}$ & $\mathrm{MW}^{\mathrm{b}}$ & Total score ${ }^{\mathrm{c}}$ & $\begin{array}{c}\text { No. of } \\
\text { hit-peptides }\end{array}$ \\
\hline 1975 & 9.2 & gil662841 & Heat shock protein 27 & 22427 & 336 & 17 \\
\hline 1694 & 4.6 & gil63252900 & Tropomyosin $1 \alpha$ chain isoform 4 & 32856 & 769 & 22 \\
\hline 1662 & 3.0 & gil48735337 & Prolyl 4-hydroxylase, $\beta$ polypeptide & 57480 & 555 & 18 \\
\hline 129 & 2.9 & gil4504763 & Integrin $\alpha-\mathrm{V}$ isoform 1 precursor & 117062 & 143 & 5 \\
\hline 321 & 2.6 & gil2202753 & Programmed cell death 6 interacting protein isoform 1 & 96590 & 519 & 9 \\
\hline 917 & 2.4 & gil12804537 & WD repeat domain 77 & 37442 & 273 & 5 \\
\hline 122 & 2.3 & gil303599 & Calpastatin & 76780 & 161 & 3 \\
\hline 2199 & 2.3 & gil5031635 & Cofilin 1 (non-muscle) & 18719 & 218 & 10 \\
\hline 170 & 2.3 & gil19743823 & Integrin $\beta 1$ isoform $1 \mathrm{~A}$ precursor & 88357 & 301 & 11 \\
\hline 1952 & 2.1 & gil5138999 & NADH-ubiquinone reductase & 30401 & 585 & 14 \\
\hline 124 & 2.1 & gil21361331 & Carbamoyl-phosphate synthetase 1 isoform b precursor & 165975 & 472 & 9 \\
\hline 1737 & -4.9 & gil38051823 & Plasminogen & 93263 & 40 & 1 \\
\hline 1177 & -2.6 & gil1168056 & Ornithine aminotransferase, OAT & 48847 & 508 & 12 \\
\hline 1056 & -2.3 & gil182439 & Fibrinogen $\gamma$ chain & 50077 & 385 & 12 \\
\hline
\end{tabular}

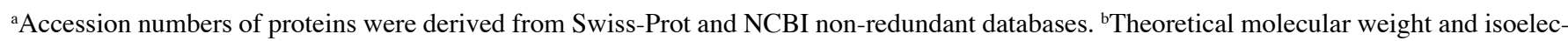
tric point obtained from the Swiss-Prot and the ExPASy database (http://us.expasy.org). ${ }^{c}$ Total score (http://www.matrixscience.com/search_ form_select.html). 

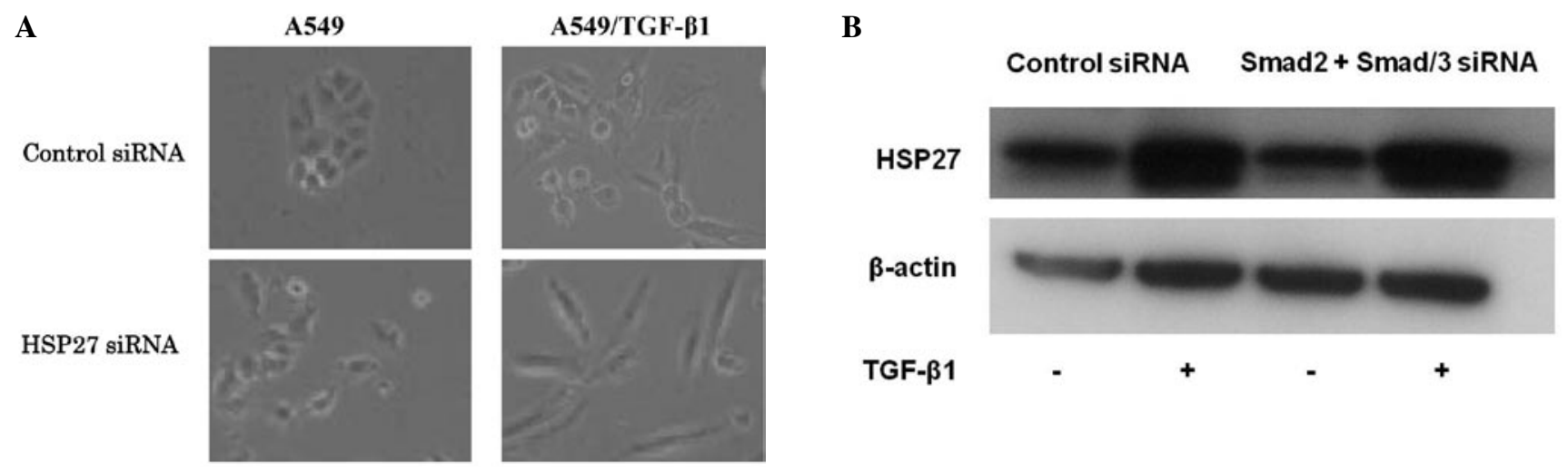

Figure 2. (A) Morphologic change of A549 cells treated with HSP27 siRNA. A549 and A549/TGF- $\beta 1$ cells were treated with control siRNA or HSP27 siRNA. A549/TGF- $\beta 1$ cells treated with HSP27 siRNA showed morphological evidence of EMT. (B) Protein expression of EMT markers in A549 and A549/TGF- $\beta 1$ cells treated with HSP27 siRNA. Loss of E-cadherin expression occurred in A549/TGF- $\beta 1$ cells treated with HSP27 siRNA, whereas a gain in N-cadherin expression was noted in A549/TGF- $\beta 1$ cells with control siRNA.

A

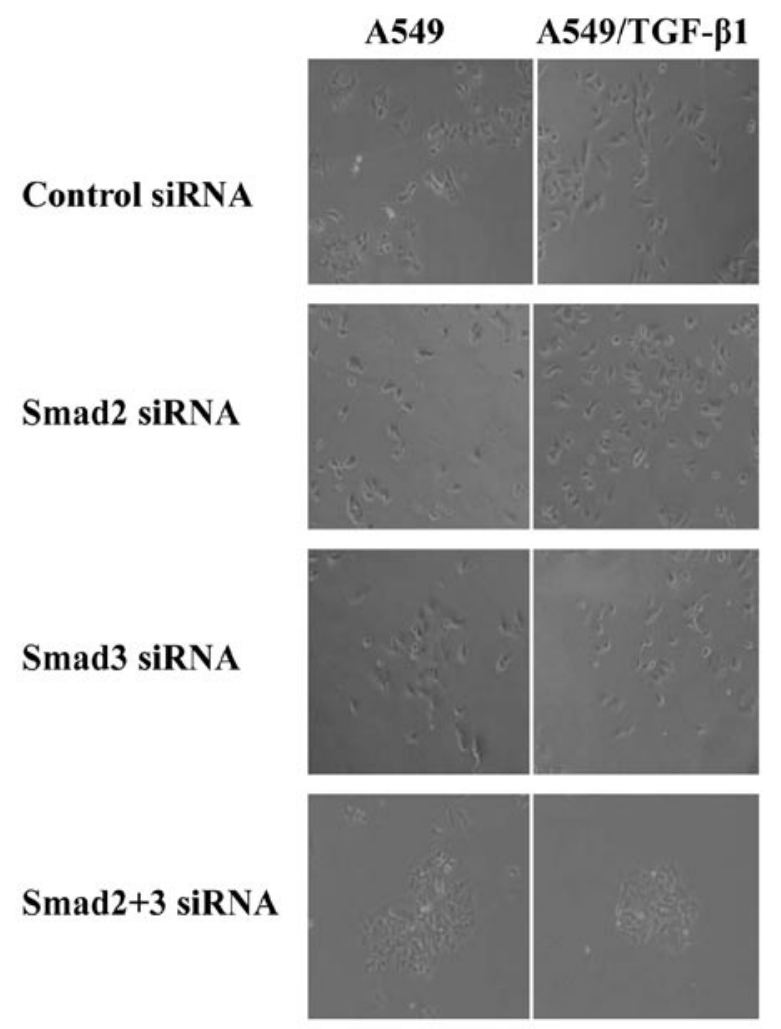

B

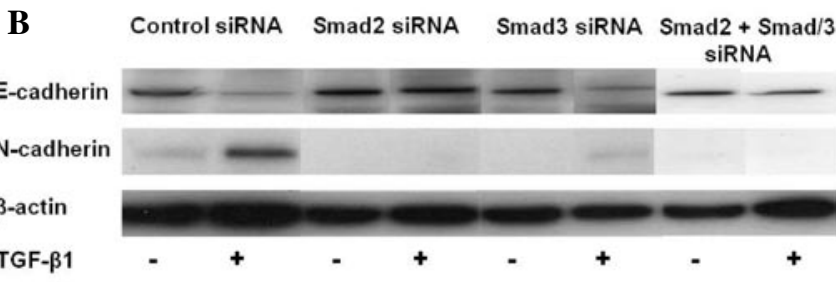

C

\section{Control siRNA Smad2 + Smad/3 siRNA}

HSP27

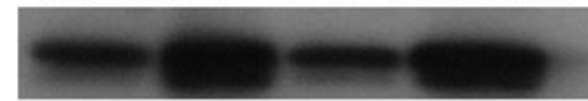

$\beta$-actin

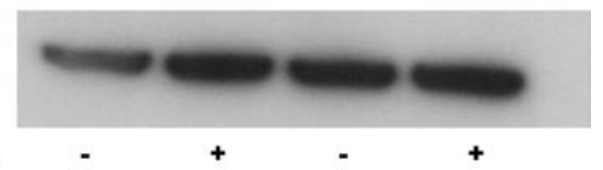

TGF- $\beta 1$

D

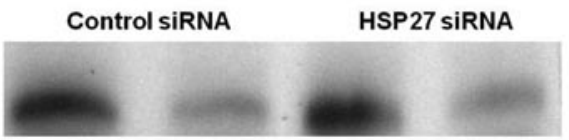

p-Smad2

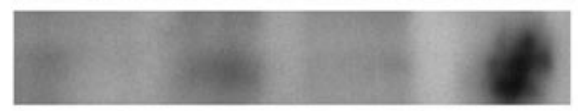

Smad3

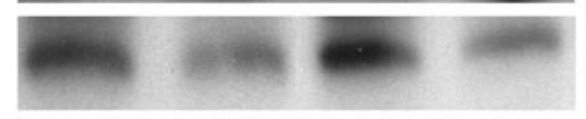

p-Smad3

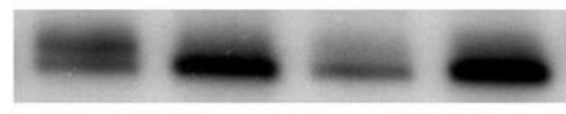

$\beta$-actin

TGF- $\beta 1$

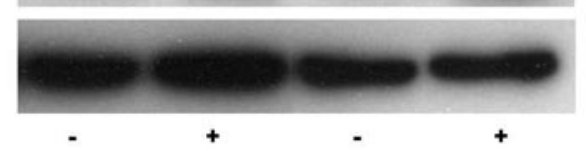

Figure 3. (A) Morphologic change of A549 cells treated with siRNA of Smad2 or Smad3. A549 and A549/TGF- $\beta 1$ cells were treated with control siRNA or siRNA of Smad2 or Smad3. A549/TGF- $\beta 1$ cells treated with Smad2 or Smad3 suppressed EMT morphologically. (B) Protein expression of EMT markers in A549 or A549/TGF- $\beta 1$ cells treated with specific siRNA of Smad2 and Smad3. A549/TGF- $\beta 1$ cells treated with Smad2- or Smad3-specific siRNA still expressed E-cadherin and suppressed N-cadherin expression. (C) Protein expression of HSP27 following the transfection of Smad2/3 double siRNA. HSP27 expression was unchanged by the transfection of Smad2- plus Smad3-specific siRNAs in A549/TGF- $\beta 1$ cells. (D) Protein expression of Smad and p-Smad of A549 cells treated with siRNA of HSP27. The expression of Smad2, Smad3, p-Smad2 and p-Smad3 was unchanged by the HSP27specific siRNA transduction.

Correlation between HSP27 and the Smad signaling pathway. The Smad signaling pathway contributes to TGF- $\beta 1$-induced EMT. Additionally, this signaling pathway modulated TGF- $\beta 1-$ induced EMT in A549 cells. A549/TGF- $\beta 1$ cells treated with siRNAs of Smad2, Smad3 or Smad2/3 suppressed the TGF- $\beta 1$-induced EMT morphologically (Fig. 3A). The expres- 
sion levels of EMT markers were examined in A549 cells following transfection of siRNA of Smad2 or Smad3. Cells depleted of Smad2 or Smad3 still expressed E-cadherin and suppressed $\mathrm{N}$-cadherin expression, resulting in the suppression of TGF- $\beta 1$-induced EMT in A549/TGF- $\beta 1$ cells (Fig. 3B). To further investigate the role of HSP27 on TGF- $\beta 1$-induced EMT, we evaluated the correlation between HSP27 and the Smad signaling pathway. HSP27 protein levels increased by exposure following the transfection of Smad2 plus Smad3 siRNAs in A549/TGF- $\beta 1$ cells (Fig. 3C). Furthermore, expression of Smad2, Smad3, p-Smad2 and p-Smad3 was unchanged by the HSP27-specific siRNA transduction (Fig. 3D). The results suggest that HSP27 was up-regulated by TGF- $\beta 1$ exposure in a Smad-independent manner and contributed to EMT in lung cancer cells.

\section{Discussion}

This is the first study to report that HSP27 is involved in TGF- 31 -induced EMT in A549 lung cancer cells and is independently activated by the Smad signaling pathway. A number of studies have demonstrated that EMT change is involved in carcinogenesis and drug resistance in lung cancer (5,10-15). For example, a significant association was found between EMT and K-Ras dependency in K-Ras-addicted lung cancer cells (5). In lung adenocarcinoma cells, thyroid transcription factor, a master regulator of lung morphogenesis, inhibited the process of EMT in response to TGF- $\beta$ (10). As for drug sensitivity, the induction of EMT contributed to the acquired resistance of epidermal growth factor receptor tyrosine kinase inhibitor in lung cancer (11-13). Thus, the inhibition of EMT is a novel potential target for the chemoprevention and treatment of lung cancer.

TGF- $\beta 1$ is a significant mediator of EMT and is involved in epithelial to mesenchymal interactions during lung carcinogenesis. The Smad pathway is a major transducer of TGF- $\beta$ signaling (21). Smad 2 and Smad 3 are phosphorylated by the TGF- $\beta$ type I receptor and form complexes with Smad4. These complexes accumulate in the nucleus of the cell, regulating the transcription of target genes and playing a crucial role in the control of cell proliferation, differentiation, apoptosis and cell migration. Apart from Smad-mediated transcription, TGF- $\beta$ type I and II receptors also allow Smadindependent TGF- $\beta$ responses. TGF- $\beta$ receptors activate alternative signaling effectors, such as mitogen-activated protein kinase, phosphatidylinositol-3-kinase and Rho-like GTPases in response to TGF- $\beta$ (21). The association between the direct activation of the Smads and other signaling pathways often defines cellular responses to TGF- $\beta$. However, the question remains as to which signaling pathway is involved in EMT in lung cancer.

HSP27 is one of the protein chaperones that transport and stabilize proteins within cells. HSP27 modulates thermotolerance, regulation of cell development and differentiation, as well as chaperone activity (22-24). HSP27 can also inhibit apoptosis by binding to cytochrome $\mathrm{c}$ and preventing its interaction with Apaf-1 and pro-caspase 9 (22). In addition, HSP27 has been shown to interact with TGF- $\beta$ (25). Numerous human tumor cells express high levels of HSP27, suggesting that HSP27 plays a role in carcinogenesis (26). In non-small cell lung cancer (NSCLC) patients, high expression levels of HSP27 are thought to inversely correlate with metastasis, poor prognosis and resistance to chemotherapy (27-29). Therefore, HSP27 is a potential diagnostic and prognostic marker in NSCLC patients. The present study showed that HSP27 was significantly up-regulated by TGF- $\beta 1$ stimulation in lung cancer cells. Furthermore, the inhibition of HSP27 enhanced TGF- $\beta 1$-induced EMT in a Smad-independent manner. HSP27 may be involved in the TGF- $\beta$ signaling pathway, although not via an EMT negative feedback loop.

In conclusion, we found that HSP27 was up-regulated by TGF- $\beta 1$-induced EMT in a Smad-independent manner in lung cancer cells. TGF- $\beta 1$, which induces EMT in lung cancers, simultaneously induced a molecule that negatively modulated EMT. Our data suggest that HSP27 provides an effective clinical strategy in lung cancer patients whose tumors are dependent on TGF- $\beta 1$-induced EMT. Further investigation of the association between HSP27 and TGF- $\beta$ signaling in lung cancer through the regulation of EMT is crucial.

\section{Acknowledgements}

We thank Dr Koichi Hagiwara for the helpful discussion.

\section{References}

1. Grünert S, Jechlinger $M$ and Beug $\mathrm{H}$ : Diverse cellular and molecular mechanisms contribute to epithelial plasticity and metastasis. Nat Rev Mol Cell Biol 4: 657-665, 2003.

2. Thiery JP: Epithelial-mesenchymal transitions in development and pathologies. Curr Opin Cell Biol 15: 740-746, 2003.

3. Thiery JP: Epithelial-mesenchymal transitions in tumour progression. Nat Rev Cancer 2: 442-454, 2002.

4. Huber MA, Kraut N and Beug H: Molecular requirements for epithelial-mesenchymal transition during tumor progression. Curr Opin Cell Biol 17: 548-558, 2005.

5. Singh A, Greninger P, Rhodes D, Koopman L, Violette S, Bardeesy $\mathrm{N}$ and Settleman J: A gene expression signature associated with 'K-Ras addiction' reveals regulators of EMT and tumor cell survival. Cancer Cell 15: 489-500, 2009.

6. Beer DG, Kardia SL, Huang CC, et al: Gene-expression profiles predict survival of patients with lung adenocarcinoma. Nat Med 8: 816-824, 2002.

7. Potti A, Mukherjee S, Petersen R, Dressman HK, Bild A, Koontz J, Kratzke R, Watson MA, Kelley M, Ginsburg GS, West M, Harpole DH Jr and Nevins JR: A genomic strategy to refine prognosis in early-stage non-small-cell lung cancer. New Eng J Med 355: 570-580, 2006.

8. Seike M, Yanaihara N, Bowman ED, Zanetti KA, Budhu A, Kumamoto K, Mechanic LE, Matsumoto S, Yokota J, Shibata T, Sugimura H, Gemma A, Kudoh S, Wang XW and Harris CC: Use of a cytokine gene expression signature in lung adenocarcinoma and the surrounding tissue as a prognostic classifier. J Natl Cancer Inst 99: 1257-1269, 2007.

9. Seike M, Goto A, Okano T, Bowman ED, Schetter AJ, Horikawa I, Mathe EA, Jen J, Yang P, Sugimura H, Gemma A, Kudoh S, Croce CM and Harris CC: MiR-21 is an EGFR regulated anti-apoptotic factor in lung cancer in never-smokers. Proc Natl Acad Sci USA 106: 12085-12090, 2009.

10. Saito RA, Watabe T, Horiguchi K, Kohyama T, Saitoh M, Nagase $T$ and Miyazono K: Thyroid transcription factor-1 inhibits transforming growth factor-beta-mediated epithelial-tomesenchymal transition in lung adenocarcinoma cells. Cancer Res 69: 2783-2791, 2009.

11. Thomson S, Buck E, Petti F, Griffin G, Brown E, Ramnarine N, Iwata KK, Gibson N and Haley JD: Epithelial to mesenchymal transition derived from repeated exposure to gefitinib determines the sensitivity to EGFR inhibitors in A549, a non-small cell lung cancer cell line. Cancer Res 65: 9455-9462, 2005. 
12. Yauch RL, Januario T, Eberhard DA, Cavet G, Zhu W, Fu L, Pham TQ, Soriano R, Stinson J, Seshagiri S, Modrusan Z, Lin CY, O'Neill V and Amler LC: Epithelial versus mesenchymal phenotype determines in vitro sensitivity and predicts clinical activity of erlotinib in lung cancer patients. Clin Cancer Res 11: 8686-8698, 2005.

13. Rho JK, Choi YJ, Lee JK, Ryoo BY, Na II, Yang SH, Kim CH and Lee JC: Epithelial to mesenchymal transition derived from repeated exposure to gefitinib determines the sensitivity to EGFR inhibitors in A549, a non-small cell lung cancer cell line. Lung Cancer 63: 219-226, 2009.

14. Soltermann A, Tischler V, Arbogast S, Braun J, Probst-Hensch N, Weder W, Moch H and Kristiansen G: Prognostic significance of epithelial-mesenchymal and mesenchymal-epithelial transition protein expression in non-small cell lung cancer. Clin Cancer Res 14: 7430-7437, 2008.

15. Bremnes RM, Veve R, Gabrielson E, Hirsch FR, Baron A, Bemis L, Gemmill RM, Drabkin HA and Franklin WA: Hirsch tissue microarray analysis used to evaluate biology and prognostic significance of the E-cadherin pathway in non-small-cell lung cancer. J Clin Oncol 20: 2417-2428, 2002.

16. Deeb G, Wang J, Ramnath N, Slocum HK, Wiseman S, Beck A and Tan D: Altered E-cadherin and epidermal growth factor receptor expressions are associated with patient survival in lung cancer: a study utilizing high-density tissue microarray and immunohistochemistry. Mod Pathol 17: 430-439, 2004.

17. Gemma A, Takenaka K, Hosoya Y, Matuda K, Seike M, Kurimoto F, Ono Y, Uematsu K, Takeda Y, Hibino S, Yoshimura A, Shibuya M and Kudoh S: Altered expression of several genes in highly metastatic subpopulations of a human pulmonary adenocarcinoma cell line. Eur J Cancer 37: 1554-1561, 2001

18. Gemma A, Li C, Sugiyama Y, Matsuda K, Minegishi Y, Noro R, Nara M, Seike M, Yoshimura A, Ogawa N, Uesaka H, Shionoya A, Kawakami A, Kosaihira S and Kudoh S: Anticancer drug clustering in lung cancer based on gene expression profiles and sensitivity database. BMC Cancer 6: 174, 2006.

19. Seike M, Kondo T, Mori Y, Gemma A, Kudoh S, Sakamoto M, Yamada $\mathrm{T}$ and Hirohashi S: Proteomic analysis of intestinal epithelial cells expressing stabilized beta catenin. Cancer Res 63 : 4641-4647, 2003.
20. Okano T, Kondo T, Fujii K, Nishimura T, Takano T, Ohe Y, Tsuta K, Matsuno Y, Gemma A, Kato H, Kudoh S and Hirohashi S: Proteomic signature corresponding to the response to gefitinib (Iressa, ZD1839), an epidermal growth factor receptor tyrosine kinase inhibitor in lung adenocarcinoma. Clin Cancer Res 13: 799-805, 2007.

21. Derynck R and Zhang YE: Smad-dependent and Smadindependent pathways in TGF-beta family signalling. Nature 425: 577-584, 2003.

22. Bruey JM, Ducasse C, Bonniaud P, Ravagnan L, Susin SA, Diaz-Latoud C, Gurbuxani S, Arrigo AP, Kroemer G, Solary E and Garrido C: Hsp27 negatively regulates cell death by interacting with cytochrome c. Nat Cell Biol 2: 645-652, 2000

23. Jia Y, Ransom R F, Shibanuma M, Liu C, Welsh MJ and Smoyer WE: Identification and characterization of hic-5/ARA55 as an hsp27 binding protein. J Biol Chem 276: 39911-39918, 2001.

24. Zhuang H, Jiang W, Cheng W, Qian K, Dong W, Cao L, Huang Q, Li S, Dou F, Chiu JF, Fang XX, Lu M and Hua ZC: Down-regulation of HSP27 sensitizes TRAIL-resistant tumor cell to TRAIL-induced apoptosis. Lung Cancer 68: 27-38, 2010.

25. $\mathrm{Xu} \mathrm{L}$, Chen $\mathrm{S}$ and Bergan RC: MAPKAPK 2 and HSP27 are downstream effectors of p38 MAP kinase-mediated matrix metalloproteinase type 2 activation and cell invasion in human prostate cancer. Oncogene 25: 2987-2998, 2006.

26. Jäättelä M: Escaping cell death: survival proteins in cancer. Exp Cell Res 248: 30-43, 2009.

27. Yao H, Zhang Z, Xiao Z, Chen Y, Li C, Zhang P, Li M, Liu Y, Guan Y, Yu Y and Chen Z: Identification of metastasis associated proteins in human lung squamous carcinoma using two-dimensional difference gel electrophoresis and laser capture microdissection. Lung Cancer 65: 41-48, 2009.

28. Malusecka E, Krzyzowska-Gruca S, Gawrychowski J, Fiszer-Kierzkowska A, Kolosza Z and Krawczyk Z: Stress proteins HSP27 and HSP70i predict survival in non-small cell lung carcinoma. Anticancer Res 28: 501-506, 2008.

29. Berrieman HK, Cawkwell L, O'Kane SL, Smith L and Lind MJ: Hsp27 may allow prediction of the response to single-agent vinorelbine chemotherapy in non-small cell lung cancer. Oncol Rep 15: 283-286, 2006. 